РОЗВИТОК ТЕОРЕТИЧНИХ ОСНОВ ІНФОРМАТИЗАЦІЇ ОСВІТИ

ТА ПРАКТИЧНА РЕАЛІЗАЦІЯ ПІДГОТОВКИ МАЙБУТНІХ УЧИТЕЛІВ НА ОСНОВІ РОЗВИТКУ КОМПЕТЕНТНОСТЕЙ STЕМ

\title{
DEVELOPMENT OF THE THEORETICAL BASIS OF EDUCATION INFORMATION AND THE PRACTICAL IMPLEMENTATION OF TRAINING OF FUTURE TEACHERS ON THE BASIS OF THE DEVELOPMENT OF COMPETENCE COMPETENCES
}

Розглянуто теоретичні основи інсрорматизації освіти, шляхи реалізації профеесійної підготовки майбутніх учителів на основі розвитку компетентностей STEM, актуальні напрями освітньої діяльност майбутніх учителів для розвитку компетентностей STEM. Охарактеризовано особливості STEM-освіти для практичної підготовки майбутніх учителів, зокрема інтегроване навчання на основі діяльнісного підходу; вміння розв'язувати конкретні наукові завдання з застосуванням засобів організації науково-дослідної роботи; фрормування стереотипу фрахівця-дослідника, який охоплює інноваційні навички роботи в лабораторії, вміння критично мислити, має здатність до комунікації $і$ співпраці, а також вміння працювати в команді, навички когнітивної гнучкості. Зазначено основні складники STEM-освіти майбутніх учителів. Зроблено аналіз науково-педагогічних досліджень $і$ виокремлено такі фрактори розвитку компетентностей STEM у прочесі підготовки майбутніх учителів: розвиток STEM-освіти, популяризація STEMпрофресій, науково-дослідницька діяльність майбутніх учителів; срормування інноваційного STEM-середовища для удосконалення науково орієнтованої та науково-технічної підготовки майбутніх учителів, підвищення рівня навичок високоорганізованого мислення; оновлення змісту освітнього процесу відповідно до пріоритетних напрямів розвитку науки і техніки; створення умов для науково-технічної діяльності майбутніх учителів відповідно до сучасних досягнень науки з використанням інноваційних методик, високотехнологічних засобів навчання; систематизацію передового педагогічного досвіду та науково-методичних матеріалів у сорері STEM-освіти; розроблення інноваційних освітніх проєктів, інтегрованих міждисциплінарних науково-дослідницьких програм. Виокремлено ключові компетентності STEM майбутніх учителів у процесі їх професійної підготовки - мовну, громадянську, інфрормаційно-цифрову, математичну, природничо-наукову, профресійно-особистісну, підприємницьку, продуктивну, соціальнокомунікативну, психолого-педагогічну, емоційно-вольову, загальнокультурну.

Ключові слова: інформатизачія освіти освітній процес, інфрормаційно-цифрові тех- нології, майбутні учителі, проєктна діяльніcUm y STEM-осBimi.

The theoretical bases of informatization of education, ways of decision of vocational training of future teachers on the basis of development of STEM competences, actual directions of educational activity of future teachers for development of STEM competencies are considered. The features of STEM education for practical training of future teachers are characterized: integrated learning based on activity approach; ability to solve specific scientific problems using the means of organization of research work; formation of the stereotype of a specialist researcher, which covers innovative skills in the laboratory, critical thinking, communication and collaboration, teamwork, cognitive flexibility. The main components of STEM education of future teachers are outlined. The analysis of scientific and pedagogical researches is made and the factors of development of STEM competences in the process of preparation of future teachers are singled out: development of STEM education, popularization of STEM professions, research activity of future teachers; formation of an innovative STEM environment for improving the science-oriented and scientific and technical training of future teachers, improving the level of highly organized thinking skills; updating the content of the educational process in accordance with priority directions of development of science and technology; creation of conditions for future teachers' scientific and technical activity in accordance with the modern achievements of science using innovative methods, high-tech teaching aids; systematization of advanced pedagogical experience and scientific and methodological materials in the field of STEM education; development of innovative educational projects, integrated interdisciplinary research programs. The key competences of future teachers' STEMs in their professional training were highlighted: language; civil; digital information; mathematical; natural science; professional and personal; entrepreneurial; productive; social and communicative; psychological and pedagogical; emotional and volitional; general cultural.

Key words: informatization of education, educational process, information-digital technologies, future teachers, project activity STEM-education. педагогічного університету імені Володимира Гнатюка

Постановка проблеми в загальному вигляді. В умовах інфрорматизації освітнього процесу у вищій школі в педагогів з'являються нові можливості керування пізнавальною діяльністю майбутніх фрахівців. Зростають вимоги до інтелектуального, наукового, культурного рівня вчителя, його професійної майстерності та творчих здібностей.
Через це одним із важливих критеріїв професіоналізму сучасного вчителя $€$ його підготовка в галузі інформатики та інформаційних технологій, які швидко стають невід'ємною складовою частиною повсякденного життя сучасної людини. Унаслідок цього істотно змінилися вимоги до сучасного фрахівця, до його особистісних і профресійних 
характеристик. Поряд із його професійними характеристиками стали гнучкість у роботі з інфрормаційними потоками й інформаційними технологіями та їх засобами, комунікативність в інформаційному просторі, мобільність у творчій діяльності та конкурентоздатність у сорері освіти [2, с. 65]. Використання інформаційних технологій в педагогічній освіті формує у майбутніх учителів перспективну орієнтацію в умовах інсрорматизації суспільства, надає їм широкий арсенал сучасних методологічних підходів і технологій оволодіння знаннями в процесі побудови цілісної картини світу, серед яких головними $є$ системний підхід, комп'ютерне моделювання та експеримент, навчальні та наукові дослідження, STEM-технології тощо [8].

Аналіз останніх досліджень і публікацій. Теоретичні засади інфоорматизації освіти та використання інсрормаційних технологій розкриваються у фрілософрських і психолого-педагогічних джерелах таких науковців: Н.Р. Балик, Ю.О. Батури, О.В. Барни, Н.О. Гончарової, О.О. Грибюк, О.О. Патрикеєвої, О.Є. Стрижак, О.Г. Шевчук, Г.П. Шмигер та ін. Концептуальні основи підготовки майбутніх учителів на основі розвитку компетентностей STEM в освітньому процесі висвітлені у працях В.Ю. Бикова, А.Ф. Верлань, Р.С. Гуревича, Ю.О. Дорошенка, М.І. Жалдака, Ю.С. Рамського, О.М. Спіріна, С.О. Семерікова, О.В. Співаковського, Н.В. Морзе, О.Г. Мороза, М.І. Шкіля та ін.

Виділення не вирішених раніше частин загальної проблеми. Упровадження STEM-освіти вимагає практичної реалізації підготовки майбутніх учителів на основі розвитку компетентностей STEM, активізує удосконалення освітніх програм і навчальних планів підготовки майбутніх учителів та розроблення високоякісних стандартів у STEMгалузях, посилює увагу практичної реалізації підготовки майбутніх учителів відповідно до нових наукових досліджень і дидактичних розробок для реалізації STEM орієнтованих проєктів, потребує організацію наукових шкіл для розвитку талановитої молоді, яка усвідомлює значущість професійних знань у контексті соціокультурного простору.

Мета статті полягає у розгляді теоретичних основ інформатизації освіти та практичної підготовки майбутніх учителів на основі розвитку компетентностей STEM.

Виклад основного матеріалу. Пріоритетними напрямами розвитку STEM-освіти на всеукраїнському рівні у 2019/2020 н.р. ДНУ «Інститут модернізації змісту освіти» зазначено такі: розроблення нормативно-правових, науково-методичних засад упровадження STEM-освіти; сприяння розвитку STEM-освіти (аналіз результативності процесу та динаміки розвитку, шляхи підвищення ефективності упровадження інновацій, виявлення проблем і прогнозування подальших тенденцій розвитку напрямів STEM-освіти); організацію та проведення освітніх заходів, спрямованих на популяризацію STEM-навчання, профрорієнтаційну роботу серед молоді; поширення досвіду та здобутків у галузі STEM-освіти шляхом публікацій, презентацій під час освітніх заходів різного рівня (міжнародних, всеукраїнських, регіональних науково-практичних конфреренцій, семінарів, вебінарів, тренінгів, круглих столів, конкурсів тощо); ініціювання, франдрайзинг та координацію інноваційних освітніх проєктів; підвищення рівня срахової майстерності науково-педагогічних працівників і представлення педагогічного досвіду роботи [6].

Із урахуванням вищезазначених пріоритетних напрямів розвитку STEM-освіти ключовими компетентностями майбутніх учителів на основі розвитку STEM-компетентностей для формування науково-дослідницької діяльності, розвитку креативного мислення, удосконалення компетентностей дослідника, підвищення особистісного та творчого потенціалу, розширення можливостей соціальної інтеграції до активного громадянства, удосконалення навичок командоутворення та керування проєктами, оволодіння новими підходами до розробки стартапів і нетворкінгу, професіоналізації та успішного працевлаштування виступають такі: мовна, громадянська, інфоормаційно-цифрова, математична, природничо-наукова, профресійно-особистісна, підприємницька, продуктивна, соціально-комунікативна, психологопедагогічна,емоційно-вольова, загальнокультурна[1].

Аналіз науково-педагогічних досліджень дав можливість виокремити такі нагальні фактори, що впливають на зацікавленість молоді у STEMосвіті: наявність прикладів для наслідування, отримання практичного досвіду, заохочення до вивчення STEM-дисциплін, розуміння практичної значущості STEM-освіти [13, с. 68; 11].

У контексті STEM-освіти компетентність майбутніх учителів розглядають як динамічну систему знань і умінь, навичок і способів мислення, цінностей і особистісних якостей, які визначають здатність до інноваційної та інформаційно-цифррової діяльності, готовність до розв'язування комплексних завдань, здатність до творчого та креативного мислення, навички розвивати організаційні здібності та уміння домовлятися, готовність до науково-дослідницької діяльності та співпраці, здатність до прийняття рішень і вмінь проявляти емоційно-когнітивний інтелект, готовність оцінювати результати своєї діяльності та критичного мислення, здатність до гнучкої та ефрективної взаємодії тощо [5].

Упровадження в освітній процес моделі STEMосвіти сприяє формуванню в майбутніх учителів таких STEM-компетентностей (умінь і навичок): виявлення та постановки проблеми дослідження з застосуванням навичок мислення високого рівня; виділення та срормулювання науково-дослідницьких завдань; знаходження шляхів творчого 
вирішення проблеми дослідження та розв'язання поставлених завдань [12].

Формування ключових компетентностей майбутніх учителів на засадах упровадження STEMосвіти потребує такого: принципово нового цілепокладання у педагогічному процесі, зміщення акцентів в освітній діяльності з вузькопредметних до загальнодидактичних; оновлення структури та змісту навчальних дисциплін і спеціальних профрільних дисциплін тощо; визначення та оцінювання результатів освітнього процесу через ключові та предметні компетентності фрахівця; запровадження наскрізного STEM-навчання, компетентнісно орієнтованих фрорм і методів навчання, системного й діяльнісного підходів; запровадження інноваційних, ігрових технологій навчання, технологій case-study, інтерактивних методів групового навчання, проблемних методик iз розвитку критичного та системного мислення тощо; корегування змісту навчальних дисциплін із акцентом на особистісно-розвивальні й інноваційні методики навчання, ціннісне ставлення до предмета наукового дослідження; створення педагогічних умов для здобуття результативного індивідуального досвіду проєктної діяльності та розробки стартапів [3].

Розвиток STEM-компетентностей у процесі підготовки майбутніх учителів передбачає таке: розвиток STEM-освіти, популяризацію STEM-професій, науково-дослідницької діяльності майбутніх учителів; формування інноваційного STEM-середовища для удосконалення науково орієнтованої та науково-технічної підготовки майбутніх учителів, підвищення рівня навичок високоорганізованого мислення на розвиток компетенцій в STEM-освіті; оновлення змісту освітнього процесу відповідно до пріоритетних напрямів розвитку науки і техніки для формування STEM-середовища; створення умов для науково-технічної діяльності майбутніх учителів відповідно до сучасних досягнень науки із використанням інноваційних методик, високотехнологічних засобів навчання; систематизацію передового педагогічного досвіду та науковометодичних матеріалів у сорері STEM-освіти для формування компетентностей, які визначають конкурентоспроможність особистості на ринку праці; розроблення інноваційних освітніх проєктів, інтегрованих міждисциплінарних науково-дослідницьких програм.

Упровадження STEM-освіти має глибинний характер і включає розв'язання проблем підготовки майбутніх учителів, які усвідомлюють свою соціальну відповідальність, постійно дбають про своє особистісне і профресійне зростання, уміють досягати нових педагогічних цілей, навчаються у процесі навчання інших. Сучасні і майбутні учителі - це активні проєктувальники міждисциплінарних освітніх програм, які на основі системи знань, розуміння наукової картини світу мають визначати зміст, обсяг і послідовність навчання, характер і ступінь інтеграції знань із різних гностичних полів, вміють добирати методи, методики і стратегії, які забезпечать найбільш очікуваний педагогічний результат [10]. Отже, від майбутніх учителів упровадження STEM-освіти вимагає активного введення в освітній процес елементів освіти майбутнього, апробації і впровадження новітніх педагогічних підходів до викладання й оцінювання, фрормування методології розвитку критичного мислення, застосування інноваційних міждисциплінарних методик навчання, зокрема й $з$ отриманням знання на основі трансдисциплінарного підходу, розвитку методів і засобів фрормування дослідницьких та інноваційних навичок в умовах оптимального психологічного клімату, збереження цілісності особистості, створення позитивної мотивації до навчання, вироблення почуття відповідальності за результати навчання, розуміння тренду навчання впродовж життя, потреби й усвідомлення необхідності систематичного підвищення професійної компетентності [9].

Актуальними напрямами освітньої діяльності майбутніх учителів на основі розвитку компетентностей STEM виступають такі: робототехніка, LEGO-конструювання, технології 3D-моделювання, мультимедійні технології, біонаноенергозбережувальні технології, інженерні розробки, що пов'язані з технічним моделюванням, електротехнікою, інтелектуальними системами.

Для практичної реалізації підготовки майбутніх учителів важливими є такі особливості STEMосвіти:

1) інтегроване навчання на основі діяльнісного підходу засобами частково пошукового та дослідницького методів. Результатами такого навчання $€$ конкретні оригінальні наукові винаходи, які можна використати на практиці для аналітичного контролю проблем конкретних досліджень;

2) уміння розв'язувати конкретні наукові завдання із застосуванням засобів організації науково-дослідної роботи, які підвищують мотивацію до фрахової підготовки, сприяють набуттю широкого спектра практичних умінь;

3) фрормування стереотипу фрахівця-дослідника, який охоплює інноваційні навички роботи в лабораторії, вміння критично мислити, комунікації та співпрацю, вміння працювати в команді, навички когнітивної гнучкості. Вказаний стереотип орієнтує майбутніх учителів на успішну власну реалізацію не тільки в профресії, а й в інших сорерах соціального життя [7, с. 163-164].

Із врахуванням основних складників STEMосвіти (багатоскладова інтеграція, синтез знань, дослідницький підхід в опануванні знань, відкритий підхід до навчання, стимуляція високого рівня мислення, досвідченість у проєктуванні, комп'ютерна 
обробка даних (аналіз, висновки), експерименти та лабораторні дослідження, створення інтерактивних моделей, конструювання, використання міжпредметних зв'язків [4]) компетентності STEM набувають особливої актуальності.

Зазначимо, що практична реалізація підготовки майбутніх учителів на основі розвитку компетентностей STEM потребує:

- готовності до розв'язання комплексних науково-практичних завдань із навичками оцінювання проблем досліджень, а також вмінь прийняття рішень;

- наявності когнітивної гнучкості, здатності до командної роботи, умінь домовлятися й працювати для успішного життя у XXI столітті, різноманітності та міжкультурної комунікації й синхронізації членів групи для реалізації проєктів та інтеграційної діяльності;

- готовності до ефективної взаємодії в STEMпроєктах і популяризації винахідницької, науководослідної діяльності;

- здатності до креативного та оригінального мислення для організації наукових шкіл для талановитої молоді, підготовки й перепідготовки кадрів;

- наявності організаційних здібностей проведення консультацій, методичних семінарів, тренінгів для реалізації STEM-програм, науковопрактичних конореренцій з обміну досвідом STEMнавчання.

Висновки. Нині важливою є організація освітнього процесу майбутніх учителів, яка потребує удосконалення умов їх професійної підготовки. Домінантою такого процесу $€$ реалізація інноваційних проєктів та науково-дослідницьких робіт здобувачів освіти й розвиток на їх основі компетентностей STEM.

\section{БІБЛІОГРАФІЧНИЙ СПИСОК:}

1. Карабін О.Й. Підготовка майбутніх учителів інфрорматики на основі розвитку компетентностей STEM. Інформаційні технології в освітньому процесі 2019 : матеріали. наук.-практ. інтернет- конфф., Чернігів, 09.12.2019-15.12.2019. Чернігів, 2019. С. $105-108$.

2. Карабін О.Й. Формування готовності майбутніх учителів гуманітарних дисциплін до роботи в інформаційному середовищі : дис. ... канд. пед. наук : 13.00.04. Тернопіль, 2013. 274 с.

3. Методичні рекомендації щодо впровадження STEM-освіти у загальноосвітніх та позашкільних навчальних закладах України на 2017/ 2018 навчальний рік. URL: https://drive.google.com/ file/d/OB3m2TqBM0APKekwtZFdhWXJuODg/view (дата звернення: 20.11.2019).

4. Морзе H. STEM: проблеми та перспективи : презентація. Київський Університет імені Б. Грінченка.

5. Проєкт концепції STEM-освіти в Україні. URL: http://mk-kor.at.ua/STEM/STEM_2017.pdf (дата звернення: 26.03.2019).

6. Середня освіта. URL: https://webcache. googleusercontent.com/search?q=cache:bcUu2WyzO 30J:https://osvita.ua/legislation/Ser_osv/65463/+\&cd=2 \&hl=uk\&ct=clnk\&gl=ua (дата звернення: 18.11.2019).

7. Сидорович M. STEM-освіта в підготовці майбутніх біологів і екологів. Актуальні питання гуманітарних наук. Серія «Педагогіка». Вип 21, т. 2. 2018. C. 162-166.

8. Сластенин В.А., Исаев И.Ф., Мищенко А.И., Шиянов Е.Н. Педагогика : учебное пособие для студентов педагогических учебных заведений. Москва : «Школа-Пресс», 2000. 512 с.

9. Штернберг Р.Дж. Интеллект, приносящий успех. Минск : ООО «Попурри», 2000.

10. Jacobs H.H. Interdisciplinary curriculum: Design and implementation. Ed. Alexandria. VA: ASDC, 1989. 97 p. URL: http://www.ascd.org/publications/ books/61189156.aspx (accessed on 12.11.2019).

11. Langdon D., McKittrick G., Beede D., Khan B., Doms M. STEM: Good jobs now and for the future. Washington, DC: U.S. Department of Commerce URL: http://www.esa.doc.gov/sites/default/files/ stemfinalyjuly14 1.pdf (accessed on 15.11.2019).

12. Partnership For 21st Century Skills. Framework for 21st Century Learning. URL: http://www.p21.org/ourwork/p21-framework (accessed on 17.11.2019).

13. Peters-Burton E.E., Lynch S.J., Behrend T.S., Means B.B. Inclusive STEM high school design: 10 critical components. Theory Into Practice. 2014. 53 (1). P. 67-71. 